\title{
Edyta Hebda' ${ }^{1}$, acek Niziol ${ }^{1}$, Jan Pielichowski ${ }^{2}$, Maciek Sniechowski ${ }^{1}$ and Malgorzata Jancia ${ }^{2}$
}

\section{PROPERTIES OF DNA COMPLEXES WITH NEW CATIONIC SURFACTANTS}

\author{
${ }^{1}$ AGH University of Science and Technology, Faculty of Physics and Applied Computer Science, \\ al. Mickiewicza 30, 30-059 Kraków, Poland; niziol@agh.edu.pl \\ ${ }^{2}$ Cracow Technical University,Department of Chemistry and Technology of Polymers, \\ ul. Warszawska 24, 31-155 Kraków, Poland
}

Received: February 17, 2011/ Revised: August 01, 2011 / Accepted: September 30, 2011

() Niziol J., Sniechowski M., Hebda E., Jancia M., Pielichowski J., 2011

\begin{abstract}
In this paper properties of deoxyribonucleic acid (DNA) complexes with originally proposed cationic surfactants are described. Properties of prepared complexes were studied with the help of UV-vis-NIR and FT-IR spectroscopies, TGA and DSC analysis and X-ray diffractometry. These complexes are intended for future applications in organic electronics.
\end{abstract}

Keywords: DNA, DNA complex, natural polymers.

\section{Introduction}

Bio-derived materials possess uncommon properties that are virtually impossible to mimic in industrial organic or inorganic materials. Furthermore, biomaterials are a renewable resource, often obtained from post-production wastes. Their nature provides inherent biodegradability. Among all available natural polymers, a range of outstanding properties are characteristic of the DNA (deoxyribonucleic acid). Its structure has already been thoroughly studied owing to its fundamental biological role [1]. DNA is a long and thin organic polymer, the rare macromolecule that represents the atomic scale in one dimension (the width equal to $2.37 \mathrm{~nm}$ ) and the human scale in another (a molecule of DNA can be many centimetres long). The molecular structure adopted by DNA is so-called double helix composed of two inter-twined strands. A single DNA strand can be viewed as a polymer built of elementary bricks referred to as nucleotides. A nucleotide contains one of four bases (adenine (A), guanine (G), cytosine (C), thymine (T)), deoxyribose sugar, and phosphate. All of the bases of a nucleotide can participate in hydrogen bonding. The specific distribution of hydrogen accepting and donating sites favours efficient hydrogen bonds only between adenine and cytosine or between guanine and thymine. As a result nucleotides pair with each other in a complementary fashion. In double-stranded DNA the distance between the two sugar-phosphate backbones is the same for each base pair. Consequently, all DNA molecules have the same regular structure in spite of the fact that their nucleotide sequences may be quite different. [2]. Each strand of the DNA molecule could serve as a template or a pattern for the synthesis of the opposite strand. This explains why DNA can be precisely copied through a natural process, running in living cells, known as DNA replication. The replication provides monodispersed molecular mass of a bulk DNA sample - a feature impossible to achieve for any of industrial polymers.

Nowadays, technology enables DNA synthesis of a tailored composition at affordable prices (less than $1 \$$ per base pair). Once obtained, a tiny DNA sample may be further infinitely artificially replicated using so called PCR technique (polymerase chain reaction). It allows amplifying the initial amount of DNA millions of times in a few hours with exponentially rising yield. All these features make DNA a well defined material.

The DNA double helix may be imagined as a tunnel of $\pi-\pi^{*}$ stacking nucleic base pairs system available for charge migration. The relatively weak $\pi-\pi^{*}$ electron conjugation renders material with a large optical transparency window (cutoff at around $300 \mathrm{~nm}$ due to absorption of bases). However, regarding the electrical charge transport it is still discussed whether the DNA belongs to the class of insulators $[3,4]$ semiconductors [5, 6], conductors [7], or even superconductors [8] of the transport in DNA molecules.

The extracted DNA is soluble exclusively in water. Due to water high surface tension and low evaporation 
rate in normal conditions, film processing through standard spin-coating technique did not lead to acceptable results. Moreover, the pristine DNA is very sensitive to hydration [9], which may substantially influence the final device performance.

A breakthrough in DNA-based technology was made by demonstrating a series of DNA-cationic surfactant complexes [10]. It was already known that DNA, which is an anionic polyelectrolyte, could be quantitatively precipitated with cationic surfactant in water by an ion exchange reaction [11]. A smart choice of cationic surfactants (cetyltrimethylammonium, cetylpyridinium, and cetylbenzyldimethylammonium) pursued to DNA-lipid complexes insoluble in water and more mechanically stable than crude DNA. Instead, the complexes were soluble in a range of common alcohols. The reasons why these surfactants were selected were as follows. Cationic surfactants bearing longer alkyl chains were water-insoluble but shorter chains might induce poorer mechanical properties. In addition, longer alkyl chains might damage the double helix structure of DNA as the strong association and aggregation among alkyl chains might dissociate the hydrogen bonds of the nucleic base pairs. Last but not least, all these surfactants were readily commercially available. Circular dichroism analysis indicated that the right-handed double helix structure of DNA was retained in the bulk complex materials. Thermodynamical analysis indicated that these film materials were of extended thermal stability. Films of best quality were those fabricated form DNA complex with cetyltrimethylammonium (CTMA). Therefore the most extensive research has been devoted to DNA-CTMA for the last decade. Now, this complex is considered as a flagship of DNA derived materials for application in photonics and molecular electronics. Such applications include: devices based on second and third order nonlinear optical effects [12], low loss optical waveguides [13], holography [14], organic photovoltaics [15], and organic field effect transistors [16]. It seems, however, reasonable to pursue the quest for new cationic surfactants, which may extend the range of possible solvents for resulting DNA complexes. Properties of two candidates to compete with CTMA are described in this paper. These are benzalkonium chloride (BA) and didecyldimethylammonium chloride (DDCA). The structures of CTMA, BA and DDCA are shown in Fig.1.

The surfactant molecule attaches its cationic head to negatively charged phosphate groups of DNA strand. In the case of CTMA aliphatic queue is supposed to stretch out. This queue hampers solubility in water and enhances in other solvents. Following such reasoning BA and DDCA surrounding DNA helix and possessing twice as much queues as CTMA does, would improve the solubility of DNA in less polar solvents.

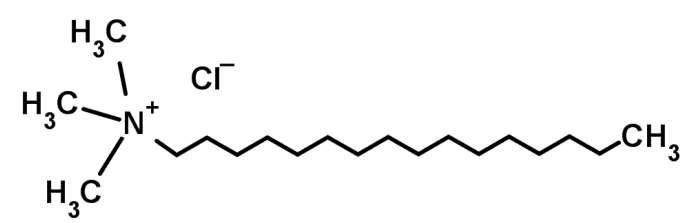

(a)

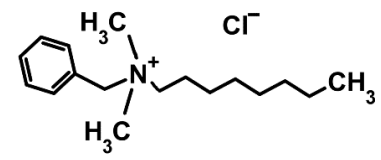

(b)

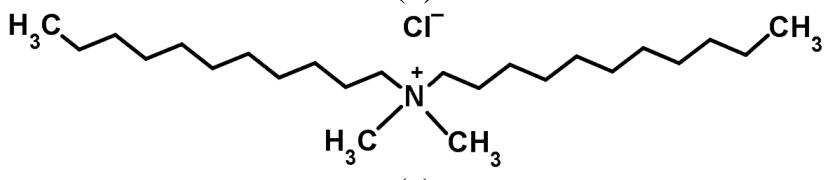

(c)

Fig. 1. Surfactants structures of CTMA (a), BA (b) and DDCA (c)

\section{Experimental}

\subsection{Sample Preparation}

DNA sodium salt, extracted from salmon milt and roe, was purchased from CIST (Chitose Institute of Science and Technology, Japan). It was isolated from frozen salmon milt and roe sacs. The claimed molecular weight was $M_{W}=10^{6}$ Daltons (Da) or 1500 base pairs and purity better than $96 \%$.

$33.3 \mathrm{ml}$ of deionized water and $200 \mathrm{mg}$ of DNA sodium salt were put in a beaker. Mechanical stirring for three hours with a magnet bar at room temperature produced clear and homogenous solution. The solution was extremely viscous. It contained entrapped air bubbles and did not let them off. It was presumed that in less viscous solution cationic surfactant would more easily penetrate to reactive centres of DNA. According to the literature data [17] sonification significantly reduces molecular weight of DNA and hence the viscosity. So the beaker was placed in ultrasounds cleaner for 100 minutes at a stabilized temperature. The temperature was close to the ambient to avoid DNA degradation. After such procedure, the solution became moderately viscous. Next cationic surfactants CTMA, BA and DDCA were dissolved in deionised water (200 $\mathrm{mg}$ in $150 \mathrm{ml}$ ). Surfactants solutions were dropwise added to the solution of DNA and constantly stirred for $20 \mathrm{~h}$. The resulted product was filtered off, washed out with deionised water and dried.

Stock solutions for thin film processing were prepared in double deionised water (pure DNA $10 \mathrm{mg} / \mathrm{ml}$ ) and in isopropanol (DNA complexes $15 \mathrm{mg} / \mathrm{ml}$ ). To 
remove any large particulates solutions were passed through a $0.2-\mu \mathrm{m}$ filter each time prior to use.

\subsection{Experimental Techniques}

Absorption spectra of the studied materials in the mid-infrared were measured in $\mathrm{KBr}$ pellets using FTIR Biorad FTS-165 spectrophotometer. Those in the visible wavelength range were recorded in solution and in solid state using Perkin Elmer Lambda 9 spectrophotometer. Thermal properties were studied using thermogravimetric analysis (TG Netzsch TG 209, argon atmosphere), differential scanning calorimetry (DSC Netzsch DSC 200) and capilary melting point apparatus (a generic model). Prior to measurements the samples were kept overnight in a vacuum drier at $310 \mathrm{~K}$. X-ray diffraction measurements were performed using Panalytical X'Pert PRO system working in grazing incidence geometry, equipped with molybdenium source and Göbel mirror. A microscope slide, thoroughly cleaned according to RCA-1 recipe, was covered with a DNA or DNA complex stock solution and horizontally placed in the diffractometer. A plastic hood with a minuscule hole was put over it to prevent rapid drying. The hood was semi cylindrical and of constant thickness in the directions of traversing X-rays. The hood did not introduce artefacts to diffractograms. Samples cast from isopropanol (DNA complexes) dried completely within $1 \mathrm{~h}$ but samples cast from water solution needed overnight drying. Temperature and humidity inside the diffractometer were stabilized at $303 \mathrm{~K}$ and $15 \%$ accordingly.

\section{Results and Discussion}

The absorption spectrum of pure DNA is pictured by uppermost curve in Fig. 2. The peaks, one can discern there, may be assigned according to available bibliographic data [18] as follows. Very broad absorption bands around $3300 \mathrm{~cm}^{-1}$ involve several components of molecular vibrations: $\mathrm{OH}$ symmetric and antisymmetric stretch modes $\left(\sim 3400 \mathrm{~cm}^{-1}\right)$, NH stretching modes $\left(\sim 3100 \mathrm{~cm}^{-1}\right.$ and $\left.\sim 3300 \mathrm{~cm}^{-1}\right)$ and overtone of a bending mode of water molecules $\left(\sim 3300 \mathrm{~cm}^{-1}\right)$. Broad bands in the range of $1600-1750 \mathrm{~cm}^{-1}$ encompass various stretching and bending modes $\left(\mathrm{C}=\mathrm{C}, \mathrm{C}-\mathrm{N}, \mathrm{C}=\mathrm{O}\right.$ and $\left.\mathrm{NH}_{2}\right)$ vibrations attributed to the base molecules. The band at $1486 \mathrm{~cm}^{-1}$ usually is attributed to purine imidazolic ring vibrations. Position and intensity of this band is very sensitive to interactions on N7 sites, particularly due to changed hydration. Bands at 1328 and $1281 \mathrm{~cm}^{-1}$ are characteristic of thymine coupled with sugar in S-type conformation. The antisymmetric and symmetric $\mathrm{PO}_{2}^{-}$ stretching bands appear at 1235 and $1091 \mathrm{~cm}^{-1}$, respectively, and are characteristic markers for nucleic acid backbone conformation, almost independent of nucleobase vibrations and sugar pucker. In the 800$900 \mathrm{~cm}^{-1}$ region, vibration along the sugar-phosphate backbone results in bands particularly sensitive to the various nucleic acid sugar puckering modes $(\mathrm{N}-$ and $\mathrm{S}$ type). Inspection of the relative intensities of these peaks may serve as a tool for estimating amounts of $\mathrm{N}$ - and $\mathrm{S}$ type sugars. The bands discussed above are traditionally taken as markers of the B-form of DNA helix. FT-IR spectra of the DNA complexes are shown also in Fig. 2, below the spectrum of DNA. The observed bands are virtually reproduced from the spectrum of the DNA with superimposed peak characteristic of the applied surfactants - symmetric and asymmetric stretching vibrations of the methylene and methyl group $\mathrm{CH}_{2}, \mathrm{CH}_{3}$ at 2942 and $2853 \mathrm{~cm}^{-1}$; C-H bending bands of methylene and methyl group $\mathrm{CH}_{2}$ and $\mathrm{CH}_{3}$ at $1454 \mathrm{~cm}^{-1}$ [19].

As shown further in Fig. 3, the UV-vis absorption spectra of DNA complexes imitate the classical spectrum of DNA, known from the literature [2]. For longer wavelengths the films retained transparency down to at least $1700 \mathrm{~nm}$ (experimental limit).

Results of solubility tests are summarised in Table 1. Solvents found inactive for all of the studied complexes were disregarded. One may notice an enhanced solubility of DNA-DDCA complex in a range of ketones and notably in chloroform, which is the most suitable for spin-coating technique among all the solvents cited in the first column of Table 1. BA was a rather disappointing choice. The only extra solvent for DNA-BA complex not working for DNA-CTMA complex was DMF (which is of rather limited practical use).

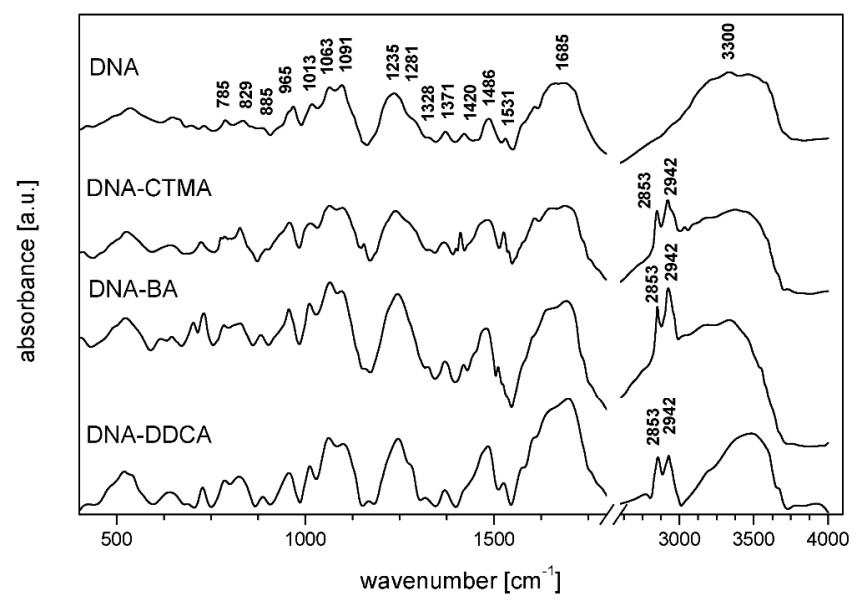

Fig. 2. FT-IR spectra of the studied DNA-surfactant complexes

Thermal stability evaluated by TGA of the studied samples can be deduced from Fig. 4. Related data are summarized in Table 2. The observed decomposition temperatures were evaluated from intersection of tangent 
lines touching the graphs before and after the region where rapid decrease of weight begins. All of them were found practically the same, c.a. equal to $500 \mathrm{~K}$. More informative is observation of the initial parts of the graphs. Despite extensive drying, the samples sill contained solvent residues and/or humidity. As it can be deduced from the second column of Table 2, DNA complexes were far less hygroscopic then the starting pure DNA sample.

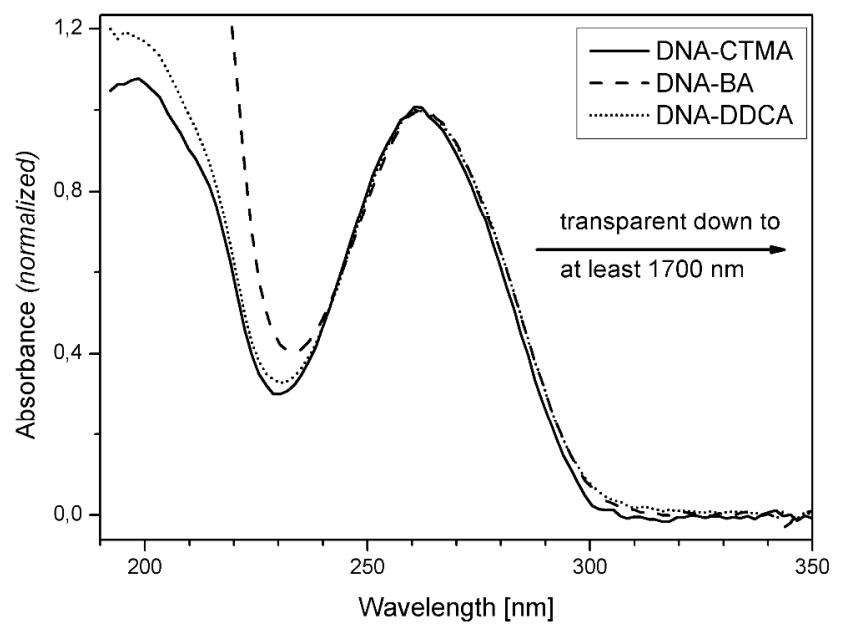

Fig. 3. UV-vis-NIR of solid

films cast on quartz substrates (the part of the spectrum without absorption for simplicity was not shown)

Table 1

\section{Solubility of DNA-surfact ant complexes}

\begin{tabular}{|l|c|c|c|}
\hline \multirow{2}{*}{\multicolumn{1}{|c}{ Solvent }} & \multicolumn{3}{c|}{ Surfactant } \\
\cline { 2 - 4 } & CTMA & BA & DDCA \\
\hline Cyclohexanone & + & + & + \\
\hline $\begin{array}{l}\text { Methyl-iso- } \\
\text { buthylketone }\end{array}$ & $+/-$ & $+/-$ & $+/-$ \\
\hline Hexanone-(2) & - & - & $+/-$ \\
\hline Metylcyclohexanone & - & - & + \\
\hline Butanone & - & - & $+/-$ \\
\hline Chloroform & - & - & + \\
\hline $\begin{array}{l}\text { DMF } \\
\text { (dimethylformamid) }\end{array}$ & - & + & + \\
\hline THF (tetrahydrofuran) & - & - & $+/-$ \\
\hline Buthanol & + & + & + \\
\hline Propanol & + & + & + \\
\hline Ethanol & + & + & + \\
\hline Water & - & - & - \\
\hline
\end{tabular}

Notes: ,,+"-soluble, ,,+--"-partly soluble, ,,-" - insoluble

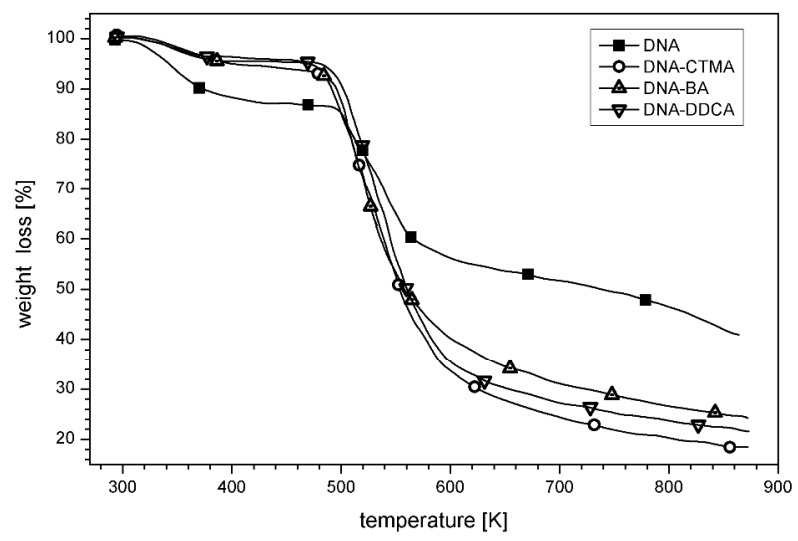

Fig. 4. Thermogravimetric analysis (TGA) graph

Table 2

\section{Data related to thermal stability deduced from TGA analysis}

\begin{tabular}{|l|c|c|c|}
\hline \multicolumn{1}{|c|}{ Sample } & $\begin{array}{c}\text { Weight } \\
\text { loss at } \\
383 \mathrm{~K}, \%\end{array}$ & $\begin{array}{c}\text { Decom- } \\
\text { position tem- } \\
\text { perature, K }\end{array}$ & $\begin{array}{c}\text { Solid } \\
\text { residue, } \\
\%\end{array}$ \\
\hline DNA & 14.0 & 499 & 41.19 \\
\hline DNA/CTMA & 4.7 & 497 & 18.53 \\
\hline DNA/BA & 4.0 & 495 & 24.90 \\
\hline DNA/DDCA & 4.1 & 501 & 21.87 \\
\hline
\end{tabular}

The heating disrupts the hydrogen bonds between base pairs and thereby causes the strands to separate. The dissociation of the double helix is often called melting because it occurs relatively abruptly at a certain temperature. In biochemical literature the melting temperature $\left(T_{m}\right)$ is defined as the temperature at which half of the helical structure is lost. The reverse process is called annealing. In terms used in polymer science such transition would be rather described as glass transition. Typically such defined $T_{m}$ lies in the range between c.a. 340 and $380 \mathrm{~K}$ and depends on DNA composition [20]. In DSC plots shown in Fig. 5, very tiny hatchbacks can be discerned in the vicinity of the upper limit of this range. The values of $T_{m}$ cannot be determined from this data with enough accuracy to draw reliable conclusions regarding a hypothetical dependence of this transition on DNAsurfactant composition. Endothermic peaks characteristic of true melting can be seen at temperatures above $430 \mathrm{~K}$. These melting temperatures are lower in the case of DNACTMA and DNA-BA than in the case of pure DNA. A reverse case may be observed for DNA-DDCA. Usually the more crystalline material the better defined its melting point. For the complexes peaks are narrower than for pure DNA, which may be attributed to a better material structural organization of the first ones. Melting point values were confirmed by capillary technique, which is presented in Table 3. 
Melting temperatures found with the help of capillary apparatus and DSC calorimetry ( $\mathrm{ramp} 2 \mathrm{~K} / \mathrm{min}$ )

\begin{tabular}{|c|c|c|c|c|}
\hline \multirow{2}{*}{ Observations } & \multicolumn{4}{|c|}{ Sample } \\
\cline { 2 - 5 } & DNA, K & DNA/CTMA, K & DNA/BA, K & DNA/DDCA, K \\
\hline Colour change & - & 427 & 427 & 441 \\
\hline Visible meniscus & - & 433 & 434 & 457 \\
\hline Liquid & - & 441 & 443 & 463 \\
\hline DSC endothermic peaks & 165 & 432 & 433 & 445 \\
\hline
\end{tabular}

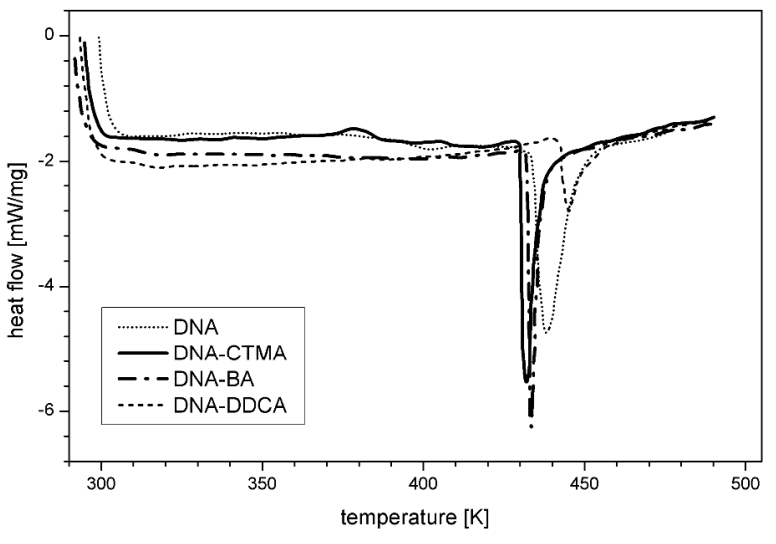

Fig. 5. Dynamic scanning calorimetric (DSC) plot

Temporal resolution of the X-ray diffraction experiment was limited by the time necessary for data collection equal to $150 \mathrm{~s}$ (single scan from $2 \theta=0.85^{\circ}$ to $6.95^{\circ}$, step $0.1^{\circ}$ ). As shown in Fig. 6, the film of pure DNA was amorphous. The others featured broad peaks. The intensities were dependent on a range of factors hard to be controlled. In order to compare the results, backgrounds were subtracted and signals normalized as shown in Fig. 7. In this graph one can see shifted maxima of diffraction peaks, apparently in relation with the type of a given surfactant. Corresponding distances between diffraction planes can be calculated as $32.5 \AA$ (DNA-

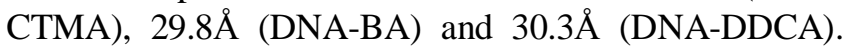
The difference between DNA-BA and DNA-DDCA is in the range of experimental uncertainty, but the value calculated for DNA-CTMA is clearly larger by $2 \AA$. This fact may be attributed to longer CTMA alkyl queue (16 carbon atoms in contrast to 11 and 8). The creation of organized structure was a temporally dynamic process like it is illustrated in Fig. 8 for DNA-CTMA complex structure. A similar behaviour was observed in the case of the two other DNA-surfactant complexes. Quantitative discussion of this phenomenon would be very risky unless the samples are prepared exactly in the same form and geometry and statistically convincing amount of data collected. Therefore the further analysis is only qualitative.

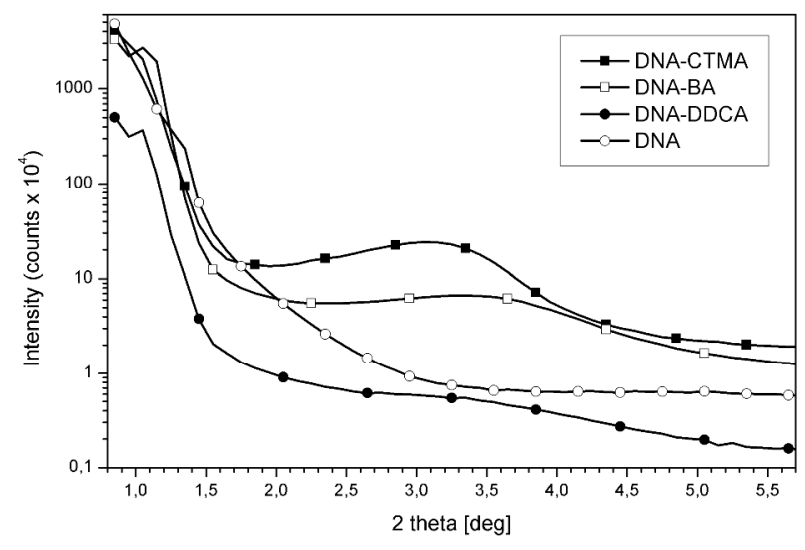

Fig. 6. Comparison of the final diffractograms (completely dried samples)

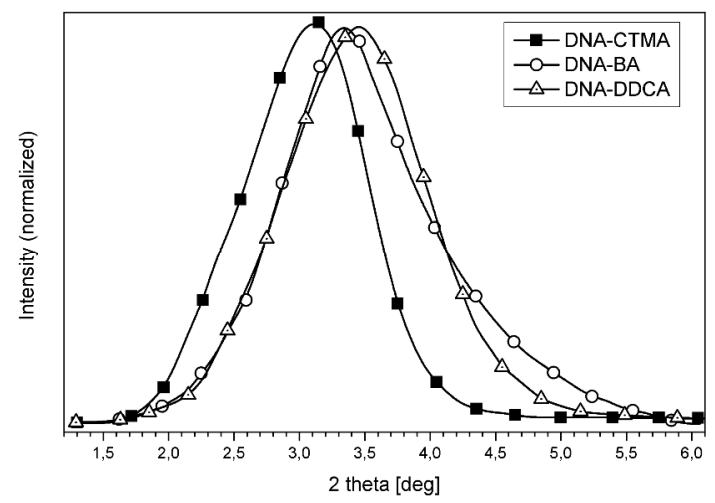

Fig. 7. Diffraction peaks after background subtraction and normalization

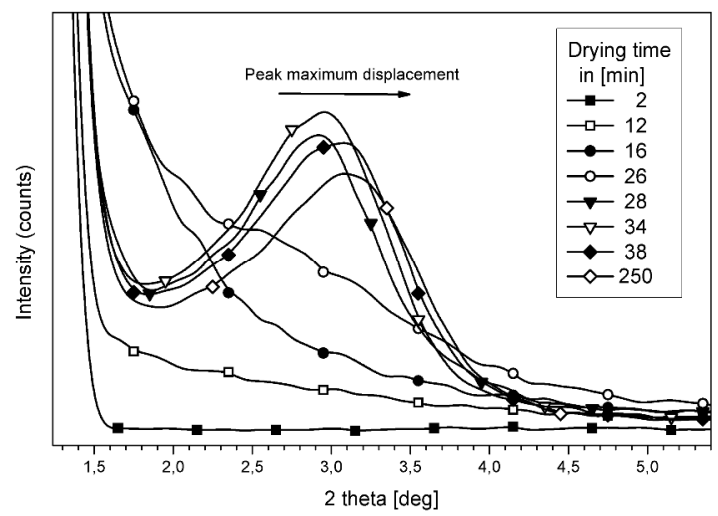

Fig. 8. DNA-CTMA. Drying process monitored on-line by X-ray diffraction. The regions without structural features were skipped in the picture 
As shown in Fig. 8 the whole transition process between amorphous and structured phases takes place between only two successive scans, recorded in 26 and 28 minutes. This suggests the existence of a critical concentration of DNA-CTMA inducing spontaneous macromolecules organization. The transition must have been relatively rapid because the whole drying process lasted $60 \mathrm{~min}$ (diffraction pattern stopped changing). The visible shift of the peak maximum before final drying may account for initially adopted liquid crystalline-like structure by DNA-CTMA complex macromolecules. They align being still surrounded by the solvent molecules. Upon successive solvent removing they approach each other until the final state is reached.

\section{Conclusions}

In this paper a new surfactant was proposed didecyldimethylammonium chloride, which enables DNA solubility in a range of practical solvents, not suitable for dissolving DNA complexes with popular surfactants, already widely applied. A close relation between the nature of the surfactant and the microstructure adopted by related DNA complex was also demonstrated.

\section{Acknowledgements}

This project was financed by Polish National Science Centre through grant no.0891/B/H03/2011/40 and by the Polish Ministry of Science and Higher Education.

\section{References}

[1] Bloomfield V., Crothers D. and Tinoco I.: Nucleic Acids: Structures, Properties, and Functions. University Science Books, Sausalito 2000.

[2] Horton R., Moran L., Scrimgeour K. et al.: Principles of Biochemistry. Pearson Prentice Hall 2006.

[3] Storm A., van Noort J., de Vries S. and Dekker C.: Appl. Phys. Lett., 2001, 79, 3881.
[4] Braun E., Eichen Y., Sivan U. and Ben-Yoseph. G.: Nature, 1998, 391, 775.

[5] Porath D., Bezryadin A., de Vries S. and Dekker C.: Nature, 2000, 403, 435.

[6] Yang Y., Yin P., Li X. and Yan Y.: Appl. Phys. Lett. 2005, 86, 203901.

[7] Fink H. and Schonenberger C.: Nature, 1999, 398, 407.

[8] Kasumov A., Kociak M., Gueron S. et al.: Science, 2001, 5502, 280.

[9] Haranczyk H., Czaka J., Nowak P. and Niziol. J.: Acta Phys. Pol. A, 2010, 112, 397.

[10] Wang L., Yoshida J. and Ogata N.: Chem. Mater., 2001, 13, 1273.

[11] Ghirlando R., Wachtel E., Arad T. and Minsky A.: Biochemistry, 1992, 31, 7110.

[12] Krupka O., El-Ghayoury A., Rau I. et al.: Thin Solid Films, 2008, 516, 8932.

[13] Grote J., Hagen J., Zetts J. et al.: J. Phys. Chem. B, 2004, 108, 8584.

[14] Fink H., Schmid H., Ermantraut E. and Schulz T.: JOSA, 1997, 14, 2168.

[15] Dutta P. and Mandal S.: J. Phys. D, 2004, 37, 2908.

[16] Yumusak C., Singh T., Sariciftci N. and Grote J.: Appl. Phys. Lett., 2009, 95, 263304.

[17] Heckman E., Hagen J., Yaney P. et al.: Appl. Phys. Lett., 2005, 87, 211115.

[18] Marechal Y.: The Hydrogen Bond and Water Molecule. Elsevier, Amsterdam 2007.

[19] Xiao W., Zhan M. and Li Z.: Materials \& Design, 2003, 24, 455 .

[20] Berg J., Tymoczko J. and Stryer L.: Biochemistry, $6^{\text {th }}$ edn. Freeman \& Co Ltd 2006.

\section{ВЛАСТИВОСТІ КОМПЛЕКСІВ ДНК 3 НОВИМИ КАТІОННИМИ ПАР}

Анотація. Описані властивості комплексів дезоксирибонуклеїнової кислоти (ДНК) з новими катіонними поверхнево-активними речовинами. За допомогою UV-vis-NIR i IЧ-Фур'є спектроскопї, ТГА і ДСК аналізу та рентгенівської дифрактометрії вивчено властивості розроблених комплексів. Показано можливість використання таких комплексів в органічній електроніці.

Ключові слова: ДНК, комплекс ДНК, природні полімери. 